\title{
Las otras educaciones en el campo pedagógico latinoamericano
}

El debate pedagógico de finales del siglo xx en América Latina nos dejó un importante legado para repensar las desigualdades y la función de la escuela en una sociedad tremendamente inequitativa. La obra de Freire y el movimiento de la educación popular marcaron de modo importante dos décadas de acción política de organizaciones de base, maestros y líderes. Las luchas indígenas que surgieron a mediados de los años 1960 implicaron un proyecto educativo para la pervivencia de sus culturas y lenguas. Los procesos reivindicativos de organizaciones negras en Sudamérica reclamaron su reconocimiento en Estados que históricamente los había invisibilizado, y el surgimiento de intelectuales antillanos, militantes de la descolonización. Los campesinos organizados en grandes ligas y federaciones reclamaron en países como Brasil, México y Colombia una educación campesina comprometida con sus culturas rurales. El feminismo, la ecología política y la lucha por los derechos sexuales se convirtieron en renovadas fuentes de discurso y acción militante. En medio de una interesante y convulsionada época, la educación estuvo en el centro del debate, por su función reproductora de ideologías de la dominación, y al mismo tiempo por su potente capacidad liberadora para el pueblo. Hacia finales del siglo xx se hermanaron las luchas sociales y las pedagogías emancipatorias, estas últimas provenientes de diversos enfoques que incluían desde la investigación acción participativa (IAP) hasta las pedagogías comunitarias y de base.

La imposición neoliberal en los años 1990 produjo importantes procesos de movilización política en torno al derecho a la educación y en defensa de lo público. Cerramos un tiempo de grandes apuestas y proyectos políticos, y vimos avanzar el multiculturalismo neoliberal y el fin de la Guerra Fría. Los archivos y la memoria viva de los procesos de las otras educaciones agenciados hace cuatro décadas empiezan a tonarse en piezas envejecidas por el paso del tiempo y el afán de una época de competencias y estándares educativos. Su vigencia es más evidente ahora que el mercado ha reducido el acto educador a un producto que se consume según la clase y el lugar del planeta que se habite. Algunos proclaman la muerte de las ideologías y el triunfo del capitalismo en la subjetividad de los nativos digitales. Pero, al mismo tiempo, las guerras de las naciones y las culturas más frágiles aparecen por las redes sociales como el anuncio de una repetida historia de exclusiones y colonizaciones a nombre de la civilización occidental.

Este número de la Revista Nodos y Nudos convocó un ejercicio colectivo para recabar en esta historia, un tanto invisible en la versión oficial de la educación latinoamericana, y bajo la denominación de las otras educaciones fue juntando voces y letras para dar cuenta de problemas y fenómenos pedagógicos herederos de las viejas batallas del siglo pasado. Las incansables agendas políticas de comunidades indígenas de Argentina y Colombia, las formas ancestrales de educación propia de los palenqueros de Colombia, las tensiones de una educación superior que pretende interculturalizarse, el papel de la diferencia étnica en los textos escolares, y el drama de la niñez indígena y afrodescendiente en las ciudades del destierro, son los planos que nos presentan las 
autoras reunidas bajo este techo editorial de la Revista Nodos y Nudos de la UPN. El ámbito de las luchas por otras educaciones y sus diacronías contiene la memoria política de los movimientos sociales y las organizaciones étnicas en sus distintas expresiones y formas, como alternativa al dispositivo de escolarización oficial.

Nos propusimos realizar una reflexión colectiva sobre estos procesos contemporáneos en un continente cuyos gobiernos avanzan agresivamente en la neoliberalización del sistema escolar y en detrimento de la condición comunitaria, en realidades diferentes y complejas que deberían, en un acto de sentido común, educar desde la diversidad en este continente multiétnico y pluricultural. El resultado son estas páginas en las que se exponen viejos problemas educativos que se manifiestan en formatos renovados, y que en todo caso contienen los asuntos históricos de la discriminación, el racismo y la injusticia curricular. De otra parte, se encuentran también las posturas y las apuestas de las otras educaciones, esas que se promueven desde las culturas afrodescendientes e indígenas, o que reclaman en escenarios como la universidad, el derecho a educarse de modo intercultural.

Educación propia, saberes ancestrales y afirmación cultural son conceptos constitutivos de estas reflexiones sobre el papel de la escuela, el currículo y la pedagogía de cara a la descolonización de nuestra educación continental, y la superación de las ataduras de la supremacía racial y la eugenesia promovidas a través de manuales y rituales escolares a mediados del siglo xx.

El trabajo de archivo sigue vigente, la producción de memorias pedagógicas es urgente y la vigencia de proyectos educativos contrahegemónicos alimenta la esperanza. De todo esto se trata el asunto de las otras educaciones y sus relatos en el siglo xxı.

Elizabeth Castillo Guzmán

Directora del Centro de Memorias Étnicas

Universidad del Cauca

Editora invitada 